\title{
PEMULIHAN PASCA BENCANA GEMPA BUMI DI LOMBOK UTARA PADA TAHUN 2018
}

\author{
Heru Kusuma Bakti ${ }^{1}$, Achmad Nurmandi ${ }^{2}$ \\ 1,2Magister Ilmu Pemerintahan Universitas Muhammadiyah Yogyakarta \\ Jalan Brawijaya, Geblagan, Tamantirto, Kec. Kasihan, Bantul, DIY, 55183, Indonesia \\ e-mail: herukusuma3@gmail.com
}

Diterima: 21 Februari 2020, Direvisi: 04 April 2020, Disetujui: 22 Juni 2020

\begin{abstract}
Abstrak
Guncangan gempa bumi berkekuatan 7.0 SR yang terjadi di Provinsi NTB khususnya Lombok Utara pada tahun 2018 yang lalu telah berdampak kepada kondisi berbagai aspek kehidupan masyarakat dan pemerintah di Kabupaten Lombok Utara, untuk itu tentu pemerintah daerah punya tanggung jawab yang lebih besar untuk melakukan pemulihan pasca terjadinya bencana hal tersebut juga tertuang dalam Undang-undang No 24 Tahun 2007, penelitian ini bertujuan untuk melihat upaya pemulihan yang dilakukan oleh pemerintah daerah melalui proses Rehabilitasi dan Rekonstruksi. Penelitian ini bersifat deskriptif dengan menggunakan metode penelitian kualitatif dan di olah dengan aplikasi Nvivo 12 Plus. Hasil menunjukan bahwa upaya yang dilakukan oleh pemerintah daerah adalah dengan melakukan Rehabilitasi dan Rekonstruksi yang telah ditetapkan melalui 5 aspek utama yaitu Sektor Sosial, Ekonomi, Infrastruktur, Pemukiman serta Lintas Sektor. Akan tetapi dalam proses Rehabilitasi dan Rekonstruksi yang dilakukan oleh Pemerintah Daerah banyak menimbulkan persoalan di masyarakat khususnya di Sektor Pemukiman, rumitnya proses birokrasi menimbulkan lambatnya pemulihan sektor pemukiman, ketidak puasan masyarakat dalam pendataan kategori rusak ringan, sedang maupun rusak berat yang dilakukan oleh pemerintah daerah serta kurangnya keterlibatan masyarakat dalam proses pemulihan juga merupakan permasalahan yang terjadi pada proses Rehabilitasi dan Rekonstruksi.
\end{abstract}

Kata kunci: Bencana, Gempa Bumi, Pemulihan Bencana, rehabilitasi dan rekonstruksi

\begin{abstract}
Shock earthquake with a magnitude of 7.0 that occurred in NTB Province, especially North Lombok in 2018, has had an impact on the conditions of various aspects of community and government life in North Lombok. Therefore, local governments have a greater responsibility to carry out recovery after the occurrence disaster, this study aims to look at the recovery efforts undertaken by the local government through the Rehabilitation and Reconstruction process. This research is descriptive in nature using a qualitative research method and treated with the application of Nvivo 12 Plus. The results show that the efforts made by the local government are to carry out the Rehabilitation and Reconstruction that have been determined through 5 main aspects namely the Social, Economic, Infrastructure, Settlement and Cross-Sector. However, in the process of Rehabilitation and Reconstruction carried out by the Regional Government, many problems in the community, especially in the Settlement Sector, the complexity of the bureaucratic process caused slow recovery of the residential sector, community dissatisfaction in the data collection categories of minor, moderate and severe damage carried out by the local government as well the lack of community involvement in the recovery process is also a problem in the Rehabilitation and Reconstruction process.
\end{abstract}

Keywords: Disasters, Earthquakes, Disaster Recovery, rehabilitation and reconstruction 


\section{PENDAHULUAN}

Secara geografis, Indonesia termasuk sebagai wilayah yang rawan terhadap berbagai kejadian bencana alam, yang dapat menimbulkan ancaman bagi masyarakat Indonesia yg disebabkan oleh baik faktor alam dan faktor manusia (perbuatan manusia). Salah satu bencana yang sering terjadi di Indonesia adalah Gempa Bumi seperti yang terjadi di Lombok Nusa Tenggara Barat pada tahun 2018 yang lalu. Bencana yang terjadi di Indonesia khususnya Lombok telah menimbulkan keperihatinan semua lapisan Masyarakat terkhususnya pemerintah yang mempunyai peran penting dalam pencegahan ataupun penanganan setelah terjadinya bencana.

Sejak satu tahun berlalu gempa berkekuatan 7.0 SR yang melanda Nusa Tenggara Barat khususnya di Kabupaaten Lombok Utara pada tanggal 5 Juli 2018 masih menyisakan duka mendalam bagi masyarakat Lombok Utara, sebagian masyarakat masih tinggal di rumah sementara karena masih trauma dan sampai saat ini gempa kecil pun masih sering terjadi. Kepulauan Nusa Tenggara Barat khususnya Lombok secara tektonik memang kawasan seismik aktif. Lombok menjadi wilayah yang rawan terhadap potensi diguncang bencana Gempa Bumi karena Lombok terletak diantara pembangkit gempa dari selatan dan utara. Sebelah selatan terdapat zona subduksi lempeng Indo-Australia yang menunjam kebawah Pulau Lombok, dari sebelah utara terdapat struktur geologi Sesar Naik Flores, yang jalurnya memanjang dari laut Bali ke timur hingga Flores, dari pada ituPulau Lombok memang rawan gempa jalur Sesar naik Flores(Tim Seismologi Teknik BMKG, 2018). Sejalan dengan Lewerissa dalam Wekke menjelaskan bahwa Gempa bumi yang menghantam Pulau Lombok disebabkan oleh lempeng tektonik Australia yang bergerak ke barat laut sampai ke utara (Wekke et al., 2019).

Semua Desa di Kabupaten Lombok Utara termasuk dalam kategori memiliki ancaman tinggi terhadap gempa bumi. Hal ini juga didukung oleh kondisi struktur geologi Pulau Lombok. Daerah Kabupaten Lombok Utara, meskipun tidak berada langsung di zona tumbukan lempeng besar seperti di Lombok bagian Selatan, tapi tumbukan pada lempeng besar tersebut juga akan bisa memicu getaran pada daerah Back Arc (Busur Belakang) dimana lokasi Kabupaten Lombok Utara menurut tatanan tektoniknya. Berikut data sebaran gempa Lombok pada Juli 2018 lalu.

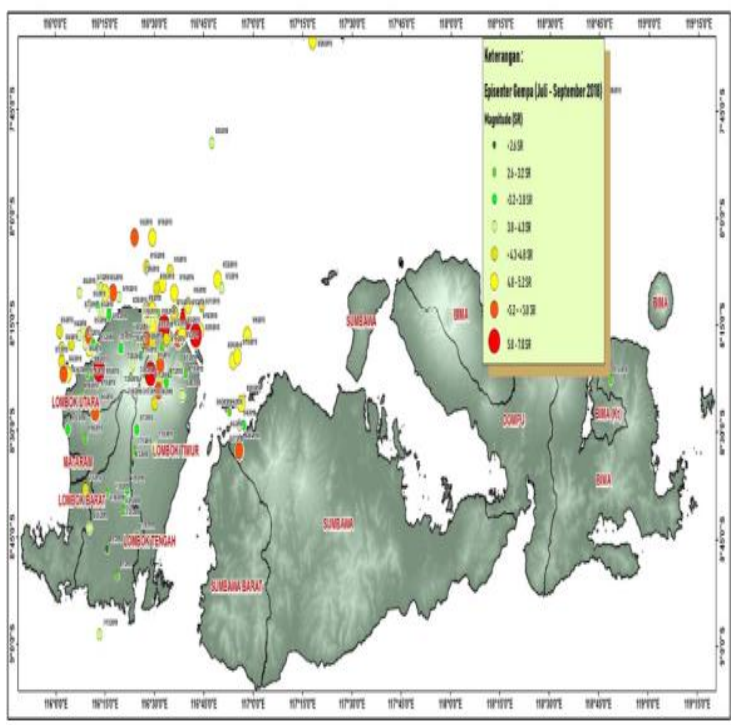

Gambar 1. Peta Sebaran Pusat Gempa Lombok pada Bulan Juli sampai dengan 13 September 2018

Dampak dari gempa di Lombok Utara menyebabkan sebanyak 537 jiwa meninggal dunia, 101.735 jiwa mengungsi, hampir 76 ribu bangunan rumah mengalami rusak berat, rusak sedang maupun rusak ringan, selain itu, berbagai fasilitas ekonomi (pasar, pertokoan, perhotelan dan akomodasi lainnya), fasilitas umum dan sosial, kantor pemerintahan, sarana dan prasarana transportasi, komunikasi, air bersih serta layanan publik lainnya terganggu. 
Tabel 1. Rekapitulasi Penilaian Kerusakan dan Kerugian

\begin{tabular}{lllll}
\hline No & Sektor & \multicolumn{1}{c}{$\begin{array}{c}\text { Nilai Kerusakan } \\
(\mathrm{Rp})\end{array}$} & $\begin{array}{c}\text { Nilai Kerugian } \\
(\mathrm{Rp})\end{array}$ & $\begin{array}{c}\text { Total Kerusakan } \\
\text { dan Kerugian } \\
(\mathrm{Rp})\end{array}$ \\
\hline 1 & Pemukiman & $3,505,485,200,000$ & $3,731,409,800,000$ & $7,236,895,000,000$ \\
2 & Infrastruktur & $303,676,794,062$ & $15,943,406,000$ & $319,620,200,062$ \\
3 & Sosial & $1,160,633,995,036$ & $169,893,013,566$ & $1,330,527,008,602$ \\
4 & Ekonomi & $\mathbf{2 7 4 , 3 1 0 , 9 7 3 , 8 3 9}$ & $\mathbf{4 2 8 , 7 1 8 , 8 2 0 , 0 0 0}$ & $\mathbf{7 0 3 , 0 2 9 , 7 9 3 , 8 3 9}$ \\
5 & Lintas Sektor & $\mathbf{2 3 5 , 1 0 4 , 2 3 5 , 2 5 0}$ & $\mathbf{1 6 6 , 0 0 9 , 0 1 7 , 6 9 8}$ & $401,113,252,948$ \\
& TOTAL & $\mathbf{5 , 4 7 9 , 2 1 1 , 1 9 8 , 1 8 7}$ & $\mathbf{4 , 5 1 1 , 9 7 4 , 0 5 7 , 2 6 4}$ & $\mathbf{9 , 9 9 1 , 1 8 5 , 2 5 5 , 4 5 1}$ \\
\hline
\end{tabular}

Sumber: Dokumen Rencana Aksi Rehab Rekon Pasca Gempa Lombok Utara 2018

Dari tabel di atas angka kerusakan dan kerugian yang di alami oleh pemerintah daerah mencapai 10 Triliun, sebagai Kabupaten baru pemerintah daerah tentunya membutuhkan dukungan dari semua pihak, dan dari tabel tersebut sektor pemukiman menjadi kerugian terbesar bagi pemerintah daerah. Dengan angka kebutuhan Rehabilitasi dan Rekonstruksi mencapai 6 Triliun, dengan komposisi rencana pendanaan dari APBN sebesar 51,04,51\% yang terdiri dari DSP BNPB, Anggaran Kementerian/Lembaga dan Usulan Hibah RR. Dana berasal dari sumber lainnya yaitu dana masyarakat dan dunia usaha sebesar 21,11\%, berasal APBD Kabupaten Lombok Utara sebesar 3,44\% dan dari APBD Provinsi NTB sebesar 0,35\%. Dalam Undang-undang No. 24 Tahun 2007 tentang penangulangan bencana juga telah mengamanatkan pemerintah baik itu pemerintah pusat maupun pemerintah daerah sebagai penyelenggara utama yang bertanggung jawab terhadap pelaksanaan kegiatan pemulihan pasca bencana (Daswati et al., 2019). Peraturan Pemerintah Nomor 21 Tahun 2008 juga menyebutkan bahwa penanggung jawab dalam penyelenggaraan penanggulangan bencana adalah Pemerintah Pusat dan Daerah sebab Pemerintah memiliki wewenang untuk melaksanakan Penanggulangan bencana mulai dari prabencana, saat tanggap darurat, hingga pascabencana. Dalam penanggulangan pasca bencana yang disebutkan pada pasal 1 ayat 10 bahwa pemerintah memiliki tanggung jawab untuk melakukan rehabilitasi dan rekonstruksi berupa perbaikan dan pemulihan dari berbagai aspek yang terdampak. Dengan demikian baik Pemerintah Pusat dan Daerah mempunyai tanggung jawab yang lebih besar terhadap pemulihan pasca bencana.

Pemulihan pasca bencana menjadi suatu kesatuan yang tidak bisa dipisahkan dengan manajemen kebencanaan yang ada di Indonesia. Manajemen bencana gempa bumi terdiri dari dua kegiatan (1) Pra bencana dan (2) Pasca bencana. Kegiatan pasca bencana, mencakup, antara lain, respons bencana / tanggap darurat, serta pemulihan bencana. Kegiatan pra bencana meliputi kesiapsiagaan, pendidikan kesadaran risiko, pelatihan, perencanaan tata ruang, dan desain struktur tahan bencana (Kholil et al., 2019).

(Army, 2015) berpendapat proses pemulihan telah menjadi salah satu langkah penting yang harus diimplementasikan setelah bencana terjadi senada dengan (Ziqiang Han, 2017) pemulihan bencana dapat dikonseptualisasikan sebagai proses diferensial memulihkan, membangun kembali, dan membentuk kembali lingkungan fisik, sosial ekonomi dan alam melalui perencanaan dan tindakan pasca terjadinya bencana, pemulihan bencana bisa menjadi peluang untuk pemerintah dalam membangun daerah agar lebih baik dan dapat bertahan pada resiko bencana yang lebih besar pada waktu mendatang. Proses pemulihan tersebut disebut sebagai fase Rehabilitasi dan Rekonstruksi 
Fase rehabilitasi dan rekonstruksi biasanya merupakan perbaikan infrastruktur dan fasilitas untuk memulihkan fungsi sosial dan ekonomi daerah yang terkena bencana sedangkan fase rekonstruksi muncul sebagai restorasi jangka panjang yang tidak hanya mencakup perbaikan fisik masyarakat yang terkena dampak tetapi juga kebangkitan mata pencaharian, ekonomi, industri, budaya, tradisi, dan lingkungan (Ong, Jamero 2016). Proses pemulihan pasca bencana tentu membutuhkan waktu beberapa minggu hingga lebih dari satu tahun, tergantung pada tingkat kerusakan dan infrastruktur yang akan diperbaiki. Phillips dalam (Sagala \& Lutfiana, 2015) mengatakan pada fase pemulihan pasca bencana pembangunan kembali dari berbagai aspek lebih menitikberatkan pada pembangunan jangka panjang, pemulihan pasca bencana melputi beberaapa aspek yang menjadi fokus pemerintah yaitu Sektor Perumahan, Ekonomi, Lingkungan Infrastruktur, Sosial Psikologis dan Pelayanan Publik. (Horney et al., 2018) berpendapat pemulihan bencana yang baik harus mendukung peningkatan dalam perencanaan mitigasi, kesiapan, dan pengembangan yang akan berkontribusi pada peningkatan ketahanan bencana di masa depan. Untuk itu pemerintah tidak hanya memberikan pelayanan kepada masyarakat akan tetapi mempersiapkan resioko bencana yang akan datang dengan melihat perencanaan mitigasi, kesiapan dan sebagainya, apalagi Lombok masih mempunyai resiko bencana Gempa besar yang akan datang. United Nations Development Programme (UNDP) pada artikelnya juga menjelaskan bahwa proses pemulihan pasca terjadinya bencana mencakup 4 bidang yang harus terpenuhi dengan berfokus pada : (1) Pemulihan sektor ekonomi, (2) Sektor pelayanan publik seperti pendidikan, kesehatandan serta pelayanan publik lainnya (3) Perumahan yang terdampak bencana, (4) Sektor infrastruktur (UNDP, 2015).

Sampai pada saat ini kegiatan pemulihan pasca bencana masih dilakukan oleh pemerintah Lombok Utara dan tentu tidak cukup sampai 1 atau 2 tahun kedepan untuk mengembalikan fungsi penghidupan masyarakat seperti sebelum terjadinya bencana dan dari pada itu penulis akan membahas tentang upaya pemulihan yang dilakukan oleh pemerintah Lombok Utara pasca bencana gempa bumi yang terjadi di NTB pada tahun lalu khususnya di Lombok Utara di berbagai sektor seperti Pemukiman, Infrastruktur, Ekonomi, Sosial, dan Lintas Sektor.

\section{METODE PENELITIAN}

Penelitian ini mengkaji tentang pemulihan pasca gempa yang terjadi di Nusa Tenggara Barat khususnya di Lombok Utara pada tahun 2018 yang lalu, penelitian ini menggunakan pendekatan metode deskriftif kualitatif, data primer yang digunakan oleh peneliti ialah dokumen perencanaan rehabilitasi dan rekonstruksi yang telah di tetapkan oleh pemerintah daerah dan data sekunder di ambil dari berita online terkait rehabilitasi dan rekonstruksi pasca gempa Lombok Utara yang bisa di pertanggung jawabkan tingkat keakuratannya, dan data tersebut di olah dengan menggunakan aplikasi Nvivo 12 Plus setalah di lakukan pengcodingan langkah yang dilakukan selanjutnya adalah dengan menggunakan crostab untuk melihat upaya-upaya yang dilakukan oleh Pemerintah Daerah dalam proses rehabilitasi dan rekonstruksi.

\section{HASIL DAN PEMBAHASAN}

\section{Pemulihan Pasca Bencana Gempa Bumi Lombok Utara Tahun 2018}

Pada bab ini peneliti akan menyajikan hasil serta pembahasan terkait pemulihan pasca bencana dalam hal ini proses rehabilitasi dan rekonstruksi yang telah di olah dari aplikasi Nvivo 12 Plus, hasil menunjukkan bahwa dalam proses pemulihan rehabilitasi dan rekonstruksi yang dilakukan oleh pemerintah Lombok Utara ditatapkan melalui Sektor Sosial, Ekonomi, Pemukiman, Infrastruktur serta 
Lintas Sektor dan di berbagai sektor tersebut telah di tetapkan melalui sub bidang masing-masing yang telah di rencanakan melalui proses penilaian kerusakan dan kerugian, atau penilaian dan perhitungan pascabencana (JITUPASNA) yang menghasilkan estimasi kerusakan dan kerugian yang dihitung untuk 5 (lima) sektor utama tersebut.

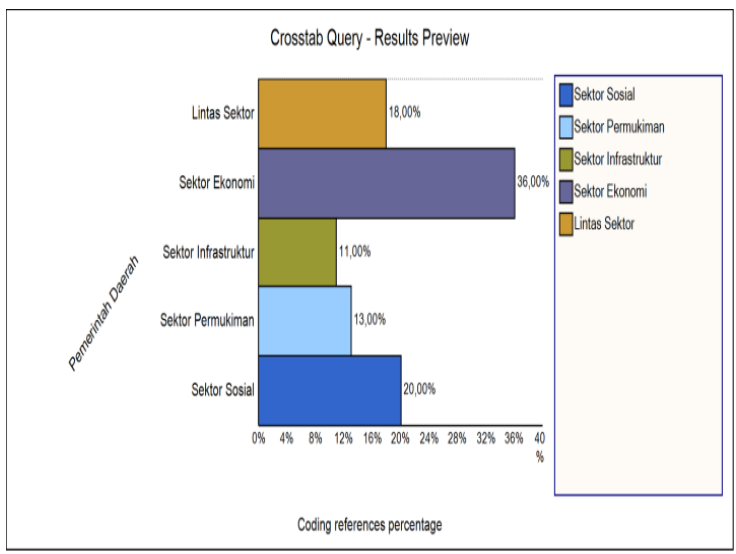

Gambar 2. Pemerintah Daerah dalam Pemulihan berbagai Sektor

Meskipun saat ini sektor pemukiman dan sosial menjadi prioritas utama dalam pemulihan pasca bencana tetapi dari grafik di atas menjelaskan bahwa sektor ekonomi lebih dominan dikarenakan dalam pengolahan data di Nvivo lebih banyak berbicara terkait dengan program yang di upayakan pemerintah bersama lembaga pemerintah lain dan swasta untuk memperbaiki kondisi ekonomi masyarakat terdampak, sebab sektor ekonomi merupakan bidang yang terpenting untuk penghidupan masyarakat yang akan datang. Menurut (Hadi, 2019) dari pengalaman pemulihan ekonomi pascabencana sebelumnya dari beberapa bencana lain yang telah dilakukan, khususnya setelah gempa Yogyakarta dan letusan Gunung Merapi, bahwa proses dan tahapan pemulihan ekonomi membutuhkan waktu yang relatif lebih lama dibandingkan dengan pemulihan bidang lain, sehingga target pemulihan yang tidak hanya pulih ke kondisi awal dapat tercapai, tetapi lebih diarahkan untuk mencapai tujuan pembangunannya dan meningkatnya kondisi ekonomi masyarakat lokal dan daerah yang lebih baik, lebih aman dan lebih berkelanjutan dalam jangka panjang untuk itu pemerintah Lombok utara harus memulihkan sektor ekonomi berbasis ketahanan untk keberlanjutan masyarakat. Pada pemulihan pasca bencana Lombok pemerintah telah menetapkan rencana aksi dalam proses Rehabilitasi dan Rekonstruksi yang meliputi Sektor Pemukiman, Sosial, Infrastruktur, Ekonomi, serta Lintas Sektor sesuai dengan peraturan yang telah ditetapkan oleh baik BNPB maupun pemerintah pusat, dibeberapa daerah juga telah dilakukan hal serupa untuk melakukan rencana aksi dalam proses rehabilitasi dan rekonstruksi. (Coffey, 2017) pada kasus pasca bencana letusan gunung Merapi dan Sinabung pemerintah juga telah menetapkan untuk melakukan proses Rehabilitasi dan Rekonstruksi melalui berbagai sektor di antaranya Sektor Pemukiman, Sosial, Infrastruktur, Ekonomi, serta Lintas Sektor. Pada kasus pasca bencana letusan merapi pemulihan awal yang dilakukan oleh pemerintah setempat meliputi memulihkan fungsi dan layanan dasar pemerintah, infrastruktur, serta kehidupan sosial, ekonomi, dan budaya masyarakat dengan cara memulihkan lembaga-lembaga sosial masyarakat yang terkena dampak yang vital untuk proses pemulihan (rehabilitasi dan rekonstruksi) jangka panjang. Memberikan stimulus untuk pemulihan mata pencaharian ekonomi dan pendapatan. Tak hanya itu penelitian (Kurnia, 2017) tentang pelaksanaan kebijakan rehab rekon perumahan pasca gempa 30 september 2009 di Sumatra Barat pemerintah menetapkan rencana aksi pemulihan pasca bencana meliputi pada kegiatan 4 sektor yaitu: Sektor Perumahan, Infrastruktur, gedung pemerintahan, Sosial, Ekonomi produktif. Berikut peneliti akan menjelaskan hasil temuan dari masing-masing sektor. 


\section{Pemulihan Sektor sosial}

Sektor sosial merupakan sektor yang terkena dampak terbesar setelah pemukiman, kebutuhan pemulihan terbesar pada sektor sosial terdapat pada sarana keagamaan 67,32\%, Pendidikan sebesar 19,42\%, Fasilitas kesehatan 11,71\% dan sarana seni budaya sebesar 1,56\%. Kerusakan pada sektor sosial di bidang pendidikan telah menyebabkan siswa tidak dapat bersekolah untuk beberapa minggu yang diakibatkan gedung sekolah hancur pasca gempa, Pelayanan kesehatan yang menurun, dan masyarakat tidak dapat melakukan ibadah di tempat-tempat ibadah. , Pemulihan di sektor sosial dilakukan di beberapa sub-sektor di bidang pendidikan, kesehatan, agama dan budaya.

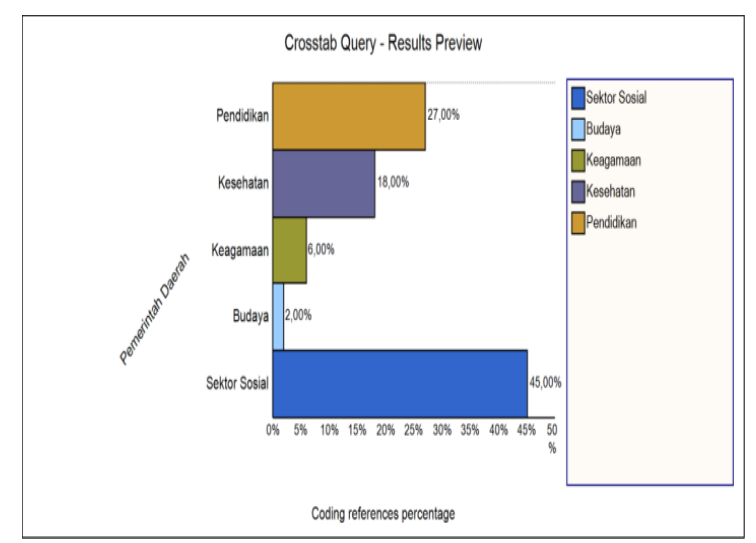

Gambar 3. Pemulihan Sektor Sosial

Dari figure hasil Nvivo 12 di atas pemulihan sektor sosial dilakukan melalui sub bidang bidang pendidikan dan kesehatan, pada bidang pendidikan hampir seluruh fasilitas pendidikan di Lombok Utara hancur mulai dari SD, SMP dan SMA serta setingkat lainnya, akibatnya banyak siswa yang tidak bisa belajar disekolahnya masing-masing, mereka menggunakan tenda-tenda darurat untuk mengikuti proses belajar mengajar. Upaya pemulihan awal yang dilakukan oleh pemerintah adalah membuat tendatenda darurat atau sekolah sementara untuk proses belajar menajar. Pemerintah juga melibatkan lembaga atau arganisasi lain dalam merekonstruksi gedung sekolah, pemerintah pusat melalui Kementerian Pendidikan dan Kebudayaan menyiapkan dana bantuan pendidikan Rp 229 miliar untuk mendukung pemulihan sarana pendukung kegiatan belajar dan mengajar pascagempa Lombok khusunya di Lombok Utara sebelumnya pemerintah telah menyediakan tenda darurat untk belajar mengajar di sekolah, sampai saat ini Dinas Dikpora Lombok Utara mengklaim pembangunan gedung sekolah mencapai $70 \%$ dan sisanya masih dalam tahap pengerjaan, untuk mengurangi resiko bencana kedepannya pemerintah daerah haruslah mendesain rekonstruksi gedung sekolah berbasis tahan terhadap gempa.

Di bidang Kesehatan hampir seluruh puskesmas dan pustu hancur akibat dari bencana Gempa Bumi, tentu masyarakat membutuhkan pelayanan kesehatan yang baik pasca terjadinya bencana, pemulihan yang dilakukan oleh pemerintah daerah pada awal masa pemulihan adalah pendirian puskesmas darurat atau sementara untuk memberikan pelayanan kesehatan bagi masyarakat yang terdampak bencana, saat ini pemerintah telah mulai membangun puskesmas melalui kementerian kesehatan pemerintah memberi bantuan dana kepada pemerintah daerah, pembangunan yang di prioritaskan pertama adalah RSUD Lombok Utara dikarenakan bangunan yang sudah tak layak pakai akibat bencana gempa, pemerintah juga mendapat dukungan dari berbagai pihak non pemerintah atau lembaga swasta dalam pembangunan fasilitas kesehatan seperti pustu, tidak hanya dari pembangunan fisik saja akan tetapi memberikan pelayanan trauma healing kepada masyarakat terutama kepada anak-anak dengan tujuan memulihkan kondisi psikologis atau trauma pasca terjadinya bencana gempa bumi. Pada aspek keagamaan juga dampak kerusakan yang tidak akibat dari bencana gempa bumi, untuk membangun kembali fasilitas ibadah masyarakat pemerintah bekerjasama dengan berbagai lembaga non pemerintah untuk membangun fasilitas 
ibadah baik semi permanan ataupun permanen. Pemerintah telah membangun gedung sekolah dengan skema tahan terhadap gempa, membangun sekolah yang tahan terhadap gempa dapat dianggap sebagai langkah pertama untuk membuat sekolah tangguh dalam menghadaapi gempa yang akan datang (Baytiyeh, 2019). Belajar dari gempa di cina Sebelum membangun gedung dilakukan survei geologis terlebih dahulu untuk mengidentifikasi topografi, geologi, dan kemudian membangun bangunan di daerah di mana bangunan tahan gempa serta diusahakan untuk menghindari lokasi bangunan yang aseismik. Perlu dicatat bahwa dalam hal apa pun, sekolah tidak boleh dibangun di atas patahan aktif, tanah longsor, atau pencairan tanah, yang berada di area tahan gempa. Ini akan mencegah gedung sekolah dari kerusakan parah akibat gempa bumi (Duan et al., 2018). Begitupun dengan gedung pelayanan kesehatan seperti Rumah Sakit dan Puskesmas pemerintah harusnya melakukan kajian mendalam terlebih dahulu, mengambil kebijakan yang tepat adalah salah satu dari keberhasilan pemulihan pasca bencana. Peneliti berpendapat bahwa untuk pemulihan pasca gempa yang terjadi perlu adanya ketahanan berbasis masyarakat dikarenakan seperti yang sudah di katakan NTB khususnya Lombok mempunyai resiko gempa yang besar di masa yang akan datang untuk perlunya membangun kesadaran masyarakat untuk bisa berdampingan dengan bencana yang akan datang, pemerintah harus memberi edukasi kepada masyarakat bagaimana memberi ketahanan terhadap bahaya bencana.

\section{Pemulihan Sektor Ekonomi}

Perekonomian di Lombok Utara pasca gempa bumi merupakan sektor yang mengalami kerugian cukup signifikan, rusaknya aset dari para pelaku usaha dan UMKM, para petani mengalami kerugian pada saat panen serta banyaknya fasilitas sarana dan prasarana dari pariwisata yang rusak dll menyebabkan terjadinya pertumbuhan ekonomi yang tidak stabil bagi pemerintah dan masyarakat. Upaya pemulihan yang dilakukan oleh pemerintah di bidang Sektor Ekonomi meliputi berbagai sub bidang di antaranya UMKM, pertanian dan perkebunan, perikanan dan peternakan, perdagangan, serta pariwisata seperti yang terlihat pada Gambar berikut.

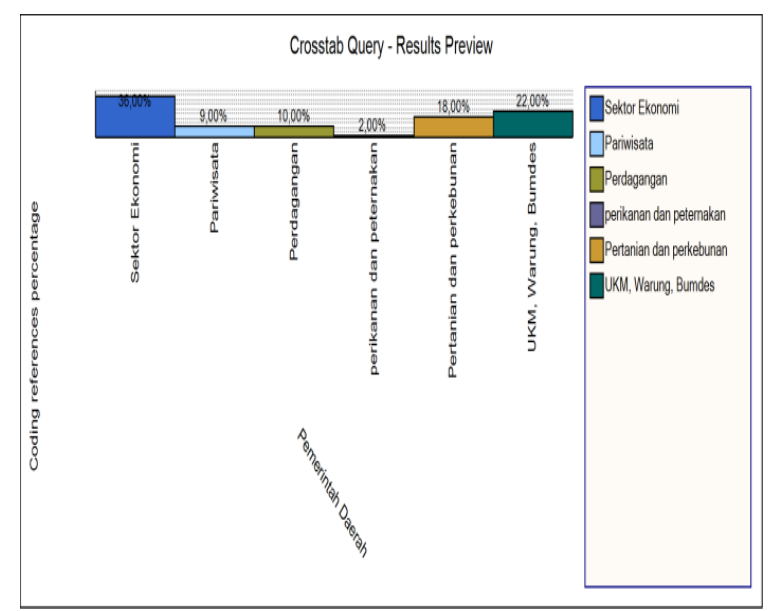

Gambar 4. Pemulihan Sektor Ekonomi

Pada pemulihan tahap awal pembangunan pasar menjadi prioritas pemerintah dalam mengembalikan kondisi ekonomi masyarakat agar perekonomian masyarakat bisa berjalan dengan baik. Dibidang UMKM yang dilakukan oleh pemerintah daerah adalah memberikan santunan kepada pelaku usaha kecil melalui kementerian, sebanyak 148 orang pedagang usaha kecil yang tersebar di beberapa kecamatan yang ada di lombok utara menerima masing-masing Rp 2 Juta untuk membantu pemulihan kondisi usaha ekonomi. Pada bidang UMKM pemerintah lebih banyak memberikan pendampingan kepada pelaku usaha dalam hal ini pemerintah bekerjasama dengan pihak non pemerintah untuk memberi pelatihan kepada pelaku usaha UMKM untk mengelola serta meningkatkan nilai jual atau meningkatkan produktifitas dari usaha yang dimiliki dengan mengelola sumber daya alam lokal, tidak pemerintah daerah 
juga berupaya menciptakan Wira Usaha Baru (WUB) bagi masyarakat dengan memberikan peralatan penunjang untuk produksi, dalam melakukan kegiatan tersebut pemerintah perlu dukungan dari semua pihak pemangku kepentingan baik di Provinsi, Pusat dan Organisasi Swasta, pada bidang pertanian upaya yang di lakukan oleh pemerintah dalam membantu petani pasca pemulihan bencana dengan melakukan pendistribusian bantuan pupuk, bibit tanaman, alat pertanian dan perkebunan melalui koperasi maupun unit usaha tani, pengadaan pelatihan manajemen lahan untuk meningkatkan kapasitas sumber daya petani dalam mengolah lahan agar semakin efektif serta pelatihan dan pendampingan usaha pertanian berkelanjutan dengan bekerjasama dengan Koperasi, BUMDES, BUMD, Pemerintah dan Swasta untuk meningkatkan produktifitas hasil pertanian dan bernilai jual karena menurut (Abraham, 2018) kejadian gempa di Lombok Utara berdasarkan waktu dan data kerugian yang dilaporkan, terjadi pada saat panen, ini yang menyebabkan pada akhirnya hasil dari panan tersebut mengalami kerugian serta penurunan kualitas dan tentu para petani akan lebih fokus untuk bisa membangun kembali rumah mereka yang rusak.

$$
\text { Pada bidang pariwisata }
$$
pemerintah memberikan bantuan atau dana stimulan untuk perbaikan sarana prasarana desa wisata serta untuk peningkatan ekonomi pelaku usaha di desa wisata selain itu melalui pemerintah pusat pemerintah daerah terus melakukan perbaikan pada fasilitas wisata yang ada di Lombok Utara dikarenakan pemasukan PAD Lombok Utara masuk melalui pariwisata. Pada pemulihan sektor ekonomi masyarakat di tuntut untuk mengembangkan ekonomi berdasarkan sumber daya potensial yang ada di sekitar, serta pengembangan ekonomi kreatif yang di dasarkan pada kearifan lokal dalam hal ini pemerintah bersama pihak swasta bersinergi dalam membantu masyarakat untuk bangkit dari keterpurukan akibat gempa. $60 \%$ Pendapatan dari pemerintah daerah berasal dari Pariwisata, meskipun perbaikan sarana-prasarana pariwisata sudah dilakukan akan tetapi itu tidak cukup untuk menarik wisatawan datang ke Lombok Utara perlu adanya langkah strategis dari pemerintah dalam pemulihan pariwisata contoh konkrit yang bisa dilakukan oleh pemerintah selain melakukan perbaikan fisik adalah dengan mengembalikan citra pariwisata Lombok Utara, karena citra merupakan kesan atau penilaian yang diberikan publik terhadap objek pariwisata yang ada di Lombok Utara pasca terjadinya gempa pada tahun 2018 pariwisata NTB khususnya Lombok Utara mendapat citra yang negatif dari berbagai wisatawan sehingga para wisatawan berfikir kembali untuk datang ke Lombok, tentu pemerintah harus berupaya sedemikian rupa untuk mengembalikan citra pariwisata yang ada d Lombok Utara. (Joakim \& Wismer, 2015) belajar dari pemulihan pasca gempa yogyakarta pada tahun 2006 untuk pemulihan sektor ekonomi masyarakat bantul membutuhkan waktu yang cukup lama untuk bisa pulih kembali, upaya yang dilakukan oleh pemerintah Bantul hampir sama dengan apa yang dilakukan oleh Pemerintah Lombok Utara sepeti memberikan pelatihan kepada pelaku UMKM dan memberikan bantuan peralatan untk mendukung usaha masyarfakat akan tetapi pemerintah tidak mendirikan lembaga keuangan mikro untuk memberikan dukungan modal pelaku usaha untuk baik pelaku usaha UMKM yang sudah terbentuk maupun akan di bentuk serta masyarakat diberi dukungan pemasaran dan jaringan untuk mempromosikan penjualan produk mereka, inilah yang harus di upayakan oleh pemerintah Lombok Utara dalam membantu para pelaku usaha UMKM sebab peralatan tanpa dukungan modal tentu tidak akan berjalan secara maksimal. Senada dengan (Dinda, 2018) dalam 
penelitian tentang pemulihan pasca bencana Gunung Sinabung pada pemulihan ekonomi pemerintah memberikan kursus keterampilan kepada masyarakat dan memberi modal untuk usaha kecil dan menengah dan pemerintah sendiri membuka lapangan pekerjaan berbasis keterampilan ekonomi kreatif.

\section{Sektor Pemukiman}

Akibat dari bencana gempa yang melanda Lombok pada tahun lalu sektor perumah merupakan sektor yang sangat besar dampaknya bagi masyarakat dan pemerintah daerah, dari data yang ada hampir 50 ribu unit rumah mengalami kerusakan baik rusak berat, sedang maupun ringan, pembangunan pemukiman nantinya di kelola dengan skema swakelola berbasis masyarakat yangdirancang menggunakan strategi pengorganisasian masyarakat serta bertumpu pada inisiatif dan prakarsa masyarakat dan tentu dengan tidak meninggalkan kearifan lokal serta gotong royong dalam membangun rumah berbasis tahan gempa,ada beberapa pilihan yang di tawarkan oleh pemerintahan kepada masyarakat seperti Risha (rumah instan sederhana sehat), Rika (rumah instan kayu) dan Riko (rumah instan konvensional). Untuk pemulihan awal yang dilakukan oleh pemerintah daerah bersama kementerian dan pihak non pemerintah atau lembaga swasta adalah membangun rumah sementara kepada masyarakat yang terdampak meskipun tidak semua mendapat bantuan serta masyarakat juga lebih banyak bergerak sendiri untuk membuat rumah sementara sebagai tempat tinggal. Pemerintah melalui Kementerian Pekerjaan Umum dan Perumahan Rakyat menyediakan dana rekonstruksi sekitar Rp50 juta per keluarga untuk mereka yang menderita kerusakan perumahan berat 25 juta per keluarga untuk mereka yang menderita kerusakan perumahan sedang dan Rp10 juta per keluarga untuk mereka yang menderita kerusakan perumahan ringan. tapi pada sampai saat rekonstruksi rumah masih menjadi permasalahan pemeintah bersama masyarakat di daerah, banyak masyarakat belum menerima haknya untuk bantuan rekonstruksi rumah tersebut, permasalahan terbesar pada pembangunan RTG tersebut ada pada proses birokrasi yang berbelit, mulai dari persoalan penerima, pokmas, nama ganda penerima, belum lagi persoalan fasilitator yang kurang, bahan bangunan yang langka SDM tukang yang minim dan masih banyak lagi. Salah satu lembaga non pemerintah yang membantu daerah dalam penanggulangan pasca bencana adalah lembaga Aksi Cepat Tanggap (ACT), bentuk kerjasama yang dilakukan ditunjukkan dengan penyediaan poskoposko pengungsian serta membuat pemukiman sementara untuk para korban bencana tak hanya itu ACT juga membangun WC Umum di beberapa tempat khususnya tempat yang jauh dari jangkauan, tak hanya ACT tetapi PMI juga telah membangun fasilitas umum berupa 20 Toilet umum serta mushola. tapi yang menjadi permasalahan sampai pada saat ini adalah banyaknya masyarakat yang masih mengeluh terhadap kualitas perumahan yang di bangun sebab banyak bangunan yang tidak sesuai dengan spek yang di tawarkan karena pekerjaan pemukiman ini melalui pihak ketiga dan masih banyaknya masyarakat yang belum mendapatkan dana stimulan untuk pembangunan rumah. Dari data yang ada jumlah total rumah rusak berat 44.014 yang sudah jadi 100 persen baru sebanyak 6.863 dengan presentase 15.59 persen. Sementara untuk rumah rusak sedang yang totalnya 1.758 unit yang sudah jadi 100 persen baru 101 unit atau 3.75 persen. Untuk rumah rusak ringan dari total 4.081 yang sudah jadi sebanyak 316 atau 7.74 persen sedangkan dari perkiraan awal pemulihan sektor permukiman dilaksanakan selama dua tahun anggaran, yakni tahun anggaran 2018-2019 dengan prioritas pembangunan rumah dilaksanakan pada tahun 2018 tetapi pada kenyataannya 
masih jauh dari yang di rencanakan (Ong et al., 2016) mengatakan Rekonstruksi perumahan adalah salah satu kegiatan terpenting pada proses rekonstruksi pascabencana, tanpa membangun kembali rumah, kemampuan rumah tangga untuk melakukan kegiatan normal akan terhambat. Untuk pemukiman yang berada di kawasan resiko rawan terhadap bencana yaitu pada sesar aktif ditetapkan kebijakan pemindahan atau relokasi ke tempat yang aman sesuai dengan rekomendasi Pusat Vulkanologi dan Mitigasi Bencana Geologi (PVMBG) melalui mekanisme relokasi komunal maupun mandiri. Adapun rumah yang berada pada zona aman dapat dilakukan pembangunan kembali/perbaikan secara in-situ (tapak semula) tetapi sampai pada pemulihan saat ini relokasi warga tidak dapat dilakukan karena berbagai pertimbangan akibatnya masyarakat tetap membangun rumah di tempat semula. Upaya untuk merehabilitasi dan rekonstruksi yang telah dilakukan pemerintah pun telah dilaksakan hingga saat ini, tetapi banyak yg menjadi masalahan saat pembangunan rumah warga dari awal pelaksanaan sampai pada saaat ini, dari keadaan birokrasi yang berbelit-belit sampai masih adanya masyarakat yang belum mernerima dana stimulan perbaikan rumah.

(Christ et al., 2017) Belajar dari pengalaman erupsi merapi 2010 tentang rekonstruksi permukiman berbasis masyarakat di Kabupaten Cangkringan pemerintah menggunakan sistem Rekompak yang diadopsi dari keberhasilan pemulihan di Aceh dan Bantul. Sistem ini menempatkan masyarakat sebagai aktor utama dalam rekonstruksi permukiman. Setiap fase dalam Rekonstruksi Permukiman Berbasis Masyarakat di Kabupaten Cangkringan seperti perencanaan, konstruksi, kontrol dan evaluasi, melibatkan masyarakat, Masyarakat mengambil peran penting dalam proses rekonstruksi, hasil dari program ini bagi masyarakat benar-benar di rasakan dengan baik. berbeda dengan yang dilakukan oleh Pemerintah Kabupaten Lombok Utara dalam rencana aksi rehabilitasi dan rekonstruksi menekankan bahwa dalam pembangunan kembali rumah warga perlunya keterlibatan masyarakat atau partisipasi masyarakat dalam pembangunan rumah akan tetapi pada kenyataannya keterlibatan masyarakat dalam perencanaan sampai pada pelaksanaan rekonstruksi rumah keterlibatan partisipasi masyarakat masih kurang, dibentuknya Kelompok Masyarakat atau POKMAS memang dinilai baik untuk membawa semangat gotong royong akan tetapi tidak berjalan secara maksimal karena sebagian besar masyarakat lebih memilih untuk menggunakan pihak ketiga dalam pembangunan rumah, dari segi pengawasan pemerintah pun masih lemah ini terlihat dari banyaknya rumah yang tidak sesuai dengan spesifikasi rumah tahan gempa, serta banyaknya aplikator yang korupsi uang dana stimulan rumah. Penelitian dari (Ophiyandri et al., 2013) mengungkapkan keberhasilan Aceh, Nias dan Yogyakarta dalam merekonstruksi perumahan di dukung oleh beberapa faktor yaitu, transparansi dan akuntabilitas, strategi / kebijakan rekonstruksi yang tepat, dan pemahaman tentang metode berbasis masyarakat, partisipasi dan kontrol masyarakat serta koordinasi dan komunikasi yang baik. Tanpa adanya transparansi dari pemerintah tentu masyarakat menaruh ketidakpercayaan kepada pemerintah serta akan berdampak kepada faktor keberhasilan yang lainnya.

Pemerintah seharusnya melakukan mengevaluasi dikarenakan banyaknya permasalahan yang masih terjadi di masyarakat khususnya rekonstruksi rumah warga sebab rekonstruksi menjadi suatu yang penting bagi kehidupan masyarakat. 


\section{Sektor Infrastruktur}

Sektor Infrastruktur merupakan sektor penting untuk mendukung kegiatan aktifitas sosial dan ekonomi masyarakat, tanpa infrastruktur yang baik tentu aktifitas sosial ekonomi masyarakat menjadi terhambat.

Terjadinya bencana gempa yang terjadi pada tahun 2018 di Lombok Utara mengakibatkan rusaknya berbagai infrastruktur yang ada dan aktifitas masyarakat menjadi terganggu serta secara tidak langsung berdampak terhadap kondisi sosial dan ekonomi masyarakat sekitar. Dari laporan yang ada angka kerugian yang di timbulkan mencapai Rp.303.676.794.062, pemulihan pada sektor Infrastruktur dilakukan melalui sub bidang di antaranya terdiri atas pemenuhan kebutuhan sub sektor transportasi baik darat laut dan sebagainya, energi, sumber daya air, pos dan komunikasi serta sanitasi dan kebutuhan air bersih.

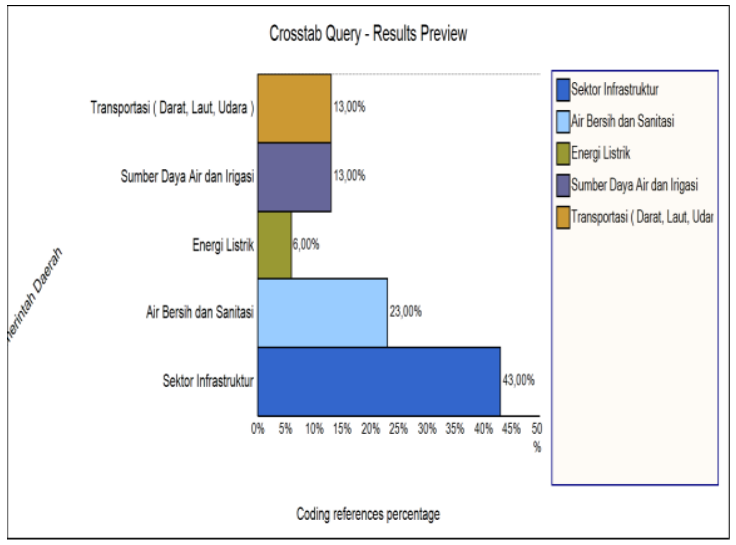

Gambar 5. Pemulihan sektor infrastruktur

Dari figure diatas dapat dilihat bahwa bidang air bersih menjadi suatu perhatian serisu dari pemerintah dan non pemerintah karena menjadi kebutuhan hidup bagi masyarakat, pemenuhan air bersih dan sanitasi pasca bencana merupakan suatu hal yang paling mendasar dan tentu menjadi priorotas dalam pemulihan pasca bencana yang terjadi di Lombok Utara terlihat dari berbagai upaya yang telah dilakukan oleh pemerintah daerah, pada saat gempa terputusnya jaringan air bersih PDAM dan sumur milik masyarakat yang tertutup akibat reruntuhan gempa membuat para warga kesulitan dalam mendapatkan air bersih, tentu dalam perbaikan jaringan PDAM tersebut membutuhkan waktu yang cukup lama. Pada bidang transportasi darat pemerintah melakukan perbaikan jalan yang mengalami kerusakan berat guna memudahkan akses baik untuk menyalurkan bantuan ataupun untuk mendukung kegiatan ekonomi masyarakat, beberapa jembatan penghubung antar wilayah saat ini juga telah selesai di rekonstruksi bersama kementerian Pekerjaan Umum. Pada bidang Sanitasi dan air bersih pemulihan awal yang dilakukan oleh pemerintah bersama lembaga terkait ataupun swasta memberikan sumur bor kepada wilayah yang terdampak terutama yang jauh dari jangkauan air dan saat ini rekonstruksi Sumber air telah selesai di kerjakan oleh institusi terkait dalam hal ini PDAM.

\section{Lintas Sektor}

Dampak yang di timbulkan pasca terjadinya gempa bumi pada lintas sektor berupa kerusakan fisik dari kantor-kantor pemerintaha yang ada di Lombok Utara sehingga menyebabkan terganggunya aktifitas pelayanan kepada masyarakat, kegiatan rehabilitasi dan rekonstruksi pasca bencana lintas sektor terdiri atas pemenuhan kebutuhan sub sektor Pemerintahan, keamanan ketertiban, Lingkungan Hidup, perbankan dan pengurangan resiko bencana, dengan perkiraan total kebutuhan sebesar Rp. 389,195,154,943 diperuntukan tersebesar untuk sub sektor pemerintahan yaitu $58,58 \%$ mengingat hampir seluruh kantor pemerintahan mengalami kerusakan berat maupun sedang. 


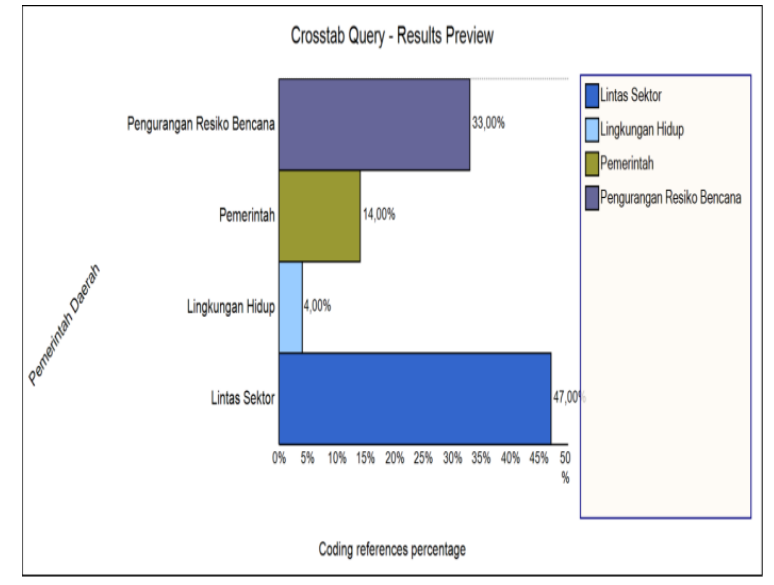

Gambar 6. Pemulihan Lintas Sektor

Meskipun dari hasil Nvivo 12 pengurangan resiko bencana mencapai 33 $\%$ tetapi prioritas awal yang dilakukan oleh pemerintah adalah pada pemulihan kembali fungsi pelayanan publik dan sarana prasarana pemerintahan seperti pembangunan tenda-tenda darurat atau kantor sementara untuk kebutuhan pelayanan kepada masyarakat. Pembangunan kembali secara permanen gedung-gedung pemerintahan yang rusak tentu akan dilakukan secara bertahap mengingat kebutuhan yang di butuhkan oleh pemerintah daerah tidaklah sedikit, seiring dengan menunggu komitmen pemerintah pusat untuk memberikan anggaran lebih kepada pemerintah Lombok Utara. Pemerintah menginginkan untuk pembangunan gedung kantor bupati diharapkan Kemendagri bisa membantu dalam hal pembiayaan. Pada bidang pengurangan resiko bencana warga yang berada di kawasan rawan bencana tinggi, diupayakan untuk di lakukan relokasi ke tempat yang aman sesuai dengan rekomendasi PVMBG karena ada beberapa wilayah berdasarkan hasil kajian di rekomendasikan untk di relokasi sebab ada sekitar 29 Dusun di dataran tinggi dinilai harus direlokasi, pemerintah juga tidak semudah itu untuk melakukan relokasi, dan yang menjadi permasalahan adalah banyak warga yang menolak di relokasi karena beberapa pertimbangan dan juga pemerintah memerlukan kajian yang lebih luas terkait dengan pembiayaan serta penghidupan masyaraka kedepannya, upaya lain yang telah di lakukan oleh pemerintah daerah dalam rangka meningkatkan pemahaman serta kesiapsiagaan masyarakat terhadap resioko bencana yang akan datang yaitu dengan memberikan sosialisasi dan memberi pelatihan pengurangan resiko bencana, serta pepemrintah telah membentuk desa siaga bencana di beberapa desa, Pendidikan dan pelatihan pengurangan risiko bencana juga telah dilakukan guna menumbuhkan dan menanamkan budaya keselamatan dan kesiapsiagaan bagi masyarakat yang berada di kawasan rawan bencana tinggi selain itu pemerintah juga membentuk sekolah siaga bencana untuk beberapa sekolah di Lombok Utara, siswa di beri pelatihan atau edukasi terkait dengan mitigasi bencana tentu ini menjadi langkah yang baik untuk pemerintah mengurangi resiko bencana untuk yang akan datang. Seperti yang di ketahui pemulihan Lintas Sektor dilakukan melalui berbagai sub bidang tetapi yang menjadi sorotan penting dalam diskusi ini adalah Pengurangan Resiko Bencana (PRB) yang akan datang sebab potensi adanya bencana di Lombok masih sangat besar untuk itu sangat penting PRB menjadi prioritas pemerintah daerah selain merekonstruksi di bidang lain. Pemerintah daerah mempunyai kapasitas atau peran penting dalam pengurangan resiko bencana, pengurangan risiko bencana menjadi suatu kebutuhan yang harus direncanakan secara sistematis oleh pemangku kepentingan dalam menghadapi resiko bencana yang akan datang, pengurangan resiko bencana berbasis masyarak bisa menjadi jawaban dalam hal tersebut pemerintah harus melibatkan masyarakat serta memberikan pendidikan kebencanaan kepada masyarakt, penelitian dari (Pascapurnama et al., 2018) belajar dari jepang negara yang rawan akan adanya resiko bencana, pendidikan bencana di Jepang telah diterapkan sejak sedini mungkin kepada anak-anak sekolah 
yang dinamakan Sekolah Siaga Bencana (SSB) pemerintah Jepang menyadari bahwa siswa adalah salah satu ujung tombak dalam pencegahan dan tanggapan bencana. Di sekolah, pendidikan bencana diatur berdasarkan Undang-Undang yang telah ditetapkan oleh pemerintah jepang serta pendidikan kebencanaan telah masuk ke kurikulum sekolah, misalnya, di tingkat sekolah dasar, siswa diajarkan mengenali jenis-jenis bencana, mengetahui peran pekerja publik seperti petugas pemadam kebakaran, dan mencegah cedera ketika terjadi bencana. Di tingkat masyarakat umum pemerintah harus melibatkan dalam hal kesiapsiagaan, tanggap darurat, dan pemulihan dari bencana alam. PRB berbasis masyarakat memungkinkan masyarakat untuk berpartisipasi secara positif dan aktif dalam rencana PRB sehingga mereka dapat diberdayakan dan memiliki peningkatan kapasitas mereka untuk mengurangi kerentanan mereka terhadap bahaya alam. Di Indonesia, kegiatan-kegiatan dalam PRB berbasis masyarakat secara umum memang telah di terapakan tetapi sangat sedikit pemerintah yang paham akan konsep dari PRB berbasis masyarakat tersebut atau tidak berjalannya secara efektif. Pasca terjadinya Gempa Bumi di Lombok Utara pemerintah memang telah menerapkan dibeberapa sekolah program Sekolah Siaga Bencana (SSB) ini merupakan langkah baik yang telah di lakukan oleh pemerintah yang perlu mencadi evaluasi adalah tidak hanya memberikan sekedar simulasi kebencanaan akan tetapi harus dimasukkan kedalam kurikulum pendidikan sekolah agar bisa bertahan pada resiko bencana mendatang serta agenda PRB harus masuk kedalam ke dalam rencana pembangunan daerah, pemerintah daerah harus mulai meninjau dan mengevaluasi rencana tata ruang yang ada untuk disinkronkan dengan rencana dan program untuk mengurangi Risiko Bencana. Dalam hal ini, BAPPEDA memiliki posisi strategis sebagai perencana PRB serta pemerintah daerah harus membuat pemetaan resiko bencana agar memudahkan dalam perencanaan PRB tersebut.

\section{KESIMPULAN}

Dari penelitian yang telah dilakukan kesimpulan ialah pemerintah lombok utara dalam melakukan pemulihan pasca bencana berfokus melalui 5 Sektor diantaranya Sektor Pemkiman, Ekonomi, Infrastruktur, Sosial dan Lintas Sektor dari berbagai sektor tersebut memiliki sub bidang pemulihan, serta pemulihan pasca bencana berpedoman kepada Inpres Nomor 5 tahun 2018 tentang percepatan Rehabilitasi dan Rekonstruksi penanganan gempa Lombok yang telah di buat oleh Presiden RI, penyusunan rencana rehabilitasi dan rekonstruksi pasca terjadinya bencana didasarkan pada hasil Pengkajian Kebutuhan Pasca Bencana (Jitu Pasna) yang telah di susun bersama lembaga pemerintah yang mempunyai wewenang dan rencana tersebut dipadukan dengan kebijakan serta kemampuan pembiayaan dari pemerintah Pusat maupun Daerah, dunia usaha atau sumber dana lainnya yang sah.Pemulihan pasca gempa lombok juga telah melibatkan berbagai lembaga kepentingan yang terkait seperti kementerian dan lembaga lain serta pihak non pemerintah atau swasta telah banyak bersinergi dengan pemerintah daera untuk membantu meringankan beban masyarakat. Pada awal masa pemulihan pasca bencana pembangunan pemukiman masyarakat, fasilitas fisik pendidikan sperti gedung sekolah serta pemulihan sektor ekonomi menjadi skala prioritas pemerintah daerah, pemulihan sektor ekonomi telah dilakukan dengan berbagai upaya pendampingan serta pelatihan kepada masyarakat khususnya pelaku UMKM akan tidak cukup kuat untuk memberikan modal ataupun keberlanjtan pemasaran yang diberikan oleh pemerintah. Meskipun pemulihan berjalan dengan baik sampai pada saat ini tetapi ada sejumlah permasalahan yang harus di jadikan bahan 
evaluasi pemerintah daerah seperti keterlambatan pembangunan Rumah Tahan Gempa (RTG) bagi masyarakat yang sampai pada saat ini juga masih banyak yang belum menerima bantuan serta masih adanya fasilitator yang bermasalah di lapangan sehingga menyebabkan terjadinya keterlambatan ini terlihat dari jumlah rumah yang dibangun masih jauh yang di harapkan.

\section{DAFTAR PUSTAKA}

Abraham, Wiwaha, A. D. (2018). Strategi Recovery Sektor Pertanian Pascabencana Gempa Di Kabupaten Lombok Utara. Journal Dialog Penanggulangan Bencana BNPB, 9(2), 102-115.

Army, B. T. H. E. (2015). Post-Disaster Housing Reconstruction in Indonesia: Review and Lessons from Aceh, Yogyakarta, West Java and West Sumatera Earthquakes. 8(1), 78-85. https://doi.org/10.1007/978-4-43154255-1

Baytiyeh, H. (2019). Why School Resilience Should Be Critical for the PostEarthquake Recovery of Communities in Divided Societies. Education and Urban Society, 51(5), 693-711. https://doi.org/10.1177/0013124517 747035

Christ, Samekto, D., \& Nuh, M. (2017). Journal of Public Administration Studies Evaluation of community-based settlement reconstruction program : Case study in post-disaster recovery of 2010 Merapi volcano eruption in Cangkringan district. 1(3), 64-70.

Coffey, M. (2017). The role of Post Disaster Needs Assessments in adressing vulnerability of Internally Displaced Persons in the Post Disaster Recovery Process. Review, 85(6), 1-22. https://doi.org/10.20955/r.85.67

Daswati, D., Samad, M. A., \& Wekke, I. S. (2019). Collaborative Governance Dalam Pengelolaan Integrated Community Shelter Pasca Bencana Di Kota Palu Collaborative Governance in the management of Integrated Community
Shelters post disaster (ICS ) in the City of Palu.

Dinda Kurnia Putri, Syafri Anwar, I. U. (2018). Jurnal kapita selekta geografi. 1(November), 56-63.

Duan, Y., Bo, J., Li, X., \& Su, Z. (2018). Earthquake damage analysis of school buildings in Jiuzhaigou. IOP Conference Series: Materials Science and Engineering, https://doi.org/10.1088/1757899X/392/4/042016

Hadi, S. (2019). Learning from The Legacy of Post-Disaster Recovery in Indonesia for The Acceleration of Post-Disaster Recovery in Lombok. Jurnal Perencanaan Pembangunan: The Indonesian Journal of Development Planning, 3(1), 14-31. https://doi.org/10.36574/jpp.v3i1.56 Horney, J. A., Dwyer, C., Chirra, B., McCarthy, K., Shafer, J., \& Smith, G. (2018). Measuring Successful Disaster Recovery. International Journal of Mass Emergencies and Disasters, 36(1), 1-22. https://www.researchgate.net/publi cation/325155344

Joakim, E. P., \& Wismer, S. K. (2015). Livelihood recovery after disaster. Development in Practice, 25(3), 401-418. https://doi.org/10.1080/09614524.20 15.1020764

Kholil, Setyawan, A., Ariani, N., \& Ramli, S. (2019). Bencana Gempa Bumi Di Lombok Propinsi Nusa Tenggara Barat ( Disaster Commuication in 4 . 0 Era: Review Earthquake Disaster Mitigation in Lombok West Nusa Tenggara ). 11(1), 0-3.

https://doi.org/10.9734/AJEE/2019 /v11i130128

Kurnia, M. L. (2017). Pelaksanaan Kebijakan Rehabilitasi dan Rekonstruksi Perumahan Pasca Gempa 30 September 2009 di Sumatera Barat. Pagaruyuang Law Journal, 1(1), 76-91. http://joernal.umsb.ac.id/index.php / pagaruyuang/index

Ong, J. M., Jamero, M. L., Esteban, M., Honda, R., \& Onuki, M. (2016). 
Challenges in Build-Back-Better Housing Reconstruction Programs for Coastal Disaster Management: Case of Tacloban City, Philippines. Coastal Engineering Journal, 58(1). https://doi.org/10.1142/S057856341 6400106

Ophiyandri, T., Amaratunga, D., Pathirage, C., \& Keraminiyage, K. (2013). Critical success factors for community-based post-disaster housing reconstruction projects in the pre-construction stage in Indonesia. International Journal of Disaster Resilience in the Built Environment, 4(2), 236-249.

https:/ / doi.org/10.1108/IJDRBE-032013-0005

Pascapurnama, D. N., Murakami, A., Chagan-Yasutan, H., Hattori, T., Sasaki, H., \& Egawa, S. (2018). Integrated health education in disaster risk reduction: Lesson learned from disease outbreak following natural disasters in Indonesia. International Journal of Disaster Risk Reduction, 29(July), 94102.

https://doi.org/10.1016/j.ijdrr.2017. 07.013
Sagala, S. Am. R. P. B. G. B. J. B. 2009, \& Lutfiana, D. (2015). Manajemen Rekonstruksi Pasca Bencana Gempa Bumi Jawa Barat 2009. 1-13.

Tim Seismologi Teknik BMKG. (2018). Ulasan Guncangan Tanah Akibat Gempa Bumi Lombok Utara.

UNDP. (2015). Supporting Nepal in Building Back Better: Livelihoods and Community Infrastructure. May.

Wekke, I. S., Rajindra, R., Pushpalal, D., Samad, M. A., Yani, A., \& Umam, R. (2019). Educational Institution on Responding Disasters in Palu of Indonesia. INA-Rxiv Papers. https://doi.org/10.31227/osf.io/drc $8 \mathrm{q}$

Ziqiang Han. (2017). Recovering from Catastrophic Disaster in Asia. https://doi.org/https://doi.org/10. 1108/S2040-726220160000018001 